\title{
Factors associated with gingival bleeding in adolescents
}

\author{
Fatores associados ao sangramento gengival em adolescentes
}

\author{
Bruna Rafaele Vieira PEDROSA ${ }^{1}$ iD 0000-0003-4246-4885 \\ Nathalia Seimi DEAMA ${ }^{1}$ iD 0000-0002-5327-7084 \\ Paulo Sávio Angeiras GOÉS ${ }^{1}$ iD 0000-0002-6708-0450 \\ Leonardo Vilar FILGUEIRAS ${ }^{1}$ iD 0000-0002-4771-7004
}

\begin{abstract}
Objective: Describe the relationship between gingival bleeding and risk factors (behavioral and psychosocial) in adolescents aged 14 to 19 years in the city of São Lourenço da Mata, Brazil. Methods: An observational, cross-sectional study was conducted with 1154 adolescents aged 14 to 19 years randomly selected from public schools located in the city of São Lourenço da Mata in the state of Pernambuco, Brazil. Socio-demographic (sex, age and race), behavioral (oral hygiene, smoking, alcohol use and leisure activities) and psychosocial (self-esteem and self-perception) data were collected through self-administered questionnaires. The presence/absence of gingival bleeding was determined using the Community Periodontal Index (CPI). The data were submitted to descriptive statistics and Pearson's chi-square test was used to determine associations between risk factors and gingival bleeding, with the significance level set at $5 \%(p<0.05)$. Results: The response rate was $80 \%$ of 1418 adolescents initially proposed to compose the sample and the prevalence of bleeding was $50.3 \%$. No associations were found between gingival bleeding and socio-demographic, behavioral or self-esteem factors. Regarding self-perception, a significant association was found between positive attitudes of satisfaction with one's physical appearance and gingival bleeding $(p<0.05)$. Conclusion: Gingival bleeding was found in most adolescents, but did not exert an influence on the satisfaction these individuals have regarding their physical appearance.
\end{abstract}

Indexing terms: Adolescents. Gingivitis. Oral health. Risk factors.

\section{RESUMO}

Objetivo: Descrever a relação do sangramento gengival com os fatores considerados de risco (comportamentais e psicossociais) em adolescentes de 14 a 19 anos da cidade de São Lourenço da Mata, Pernambuco. Métodos: Foi realizado um estudo observacional de corte transversal, com fonte de dados primários, com 1154 adolescentes de 14 a 19 anos, de ambos os sexos, selecionados de forma randomizada em escolas públicas localizadas no município de São Lourenço da Mata, Pernambuco, Brasil. Foram avaliados dados nãoclínicos: sociodemográficos (sexo, idade e raça), comportamentais (frequência de higiene oral, fumo, álcool e atividades de lazer) e psicossociais (autoestima e autopercepção) coletados através de questionários auto-aplicados e dados clínicos: presença e ausência de sangramento gengival através do Índice Periodontal Comunitário (IPC). Os dados foram apresentados de forma descritiva, onde avaliou a associação entre fatores de risco e sangramento gengival e estatística (Qui-Quadrado de Pearson). Para todas as análises foi estipulado um nivel de significância de 5\%. O estudo teve $80 \%$ de taxa de resposta de 1418 adolescentes propostos inicialmente para compor a amostra. Resultados: Constatou-se a prevalência de 50, 3\% de sangramento. Não houve associação entre sangramento gengival e fatores sociodemográficos, comportamentais e autoestima. Em relação à autopercepção, foi encontrada associação significante

\footnotetext{
$\boldsymbol{\nabla} \mathbf{v} \boldsymbol{\nabla}$

1 Universidade Federal de Pernambuco. Av. Prof. Moraes Rego, 1235, Cidade Universitária 50670-901, Recife, Pernambuco, Brasil. Correspondence to: BRV PEDROSA. E-mail: <brunarvpedrosa@gmail.com>. 
entre atitudes positivas de satisfação com a aparência física e a presença de sangramento $(p<0.05)$. Conclusão: $O$ sangramento gengival ainda está presente em grande parte dos adolescentes, porém nãoinfluencia na satisfação desses indivíduos com a sua aparência física.

Termos de indexação: Adolescentes. Gengivite. Saúde bucal. Fatores de risco.

\section{INTRODUCTION}

According to an oral health survey conducted in 2010, periodontal disease is considered one of the main oral health problems in Brazil, affecting approximately $49 \%$ of adolescents between 15 and 19 years of age [1]. Studies involving children and adolescents in Portugal, the United States, Mexico and Argentina report high prevalence rates of gingivitis, which is the most common form of periodontal disease in adolescents [2-4]. The term "periodontal disease" is used in the broad sense for all pathological conditions that affect the protection and/ or supporting structures of the periodontium, whereas gingivitis is an inflammatory processes restricted to the gingival tissues [5].

Bacteria are essential to the development of periodontal disease, but factors related to the host, such as characteristics of the individual as well as systemic, social, behavioral and psychosocial factors, exert an influence on the extent and severity of the disease $[2,6,7]$. Therefore, the lifestyle one adopts, which includes eating habits, oral hygiene habits, socioeconomic status, alcohol consumption and smoking habits, can make individuals more susceptible to the development of oral diseases $[6,8]$.

Moreover, psychosocial factors, such as personal satisfaction and psychological wellbeing [9], can exert an influence on oral health care [8] and a lack of adequate oral health can exert an influence on interpersonal relationships, affecting one's social life and self-esteem [10], which, in turn, can affect the motivation for performing oral hygiene $[11,12]$. Therefore, adolescence, which is the period spanning the second decade of life [13], is considered a phase of risk for the development of periodontal diseases, as adolescents often fail to take the necessary self-care measures care to prevent this condition, such as good oral hygiene habits and regular visits to a dentist [14].

Given that gingivitis is found in the majority of adolescents [2], prevention, early detection and periodontal treatment could result in a healthier adult population from the standpoint of oral health [15]. Therefore, the aim of the present study was to describe the relationship between gingival bleeding and risk factors (behavioral and psychosocial) in adolescents aged 14 to 19 years in the city of Lourenço da Mata, Brazil.

\section{METHODS}

An observational, cross-sectional study was conducted with primary data, which enables observing the object in loco in the population studied in a given moment in time without intervening in its course. The study was conducted in the city of São Lourenço da Mata (state of Pernambuco, northeastern Brazil) with male and female adolescents aged 14 to 19 years (born between 1995 and 1999) enrolled in the public school system. This study received approval from the Human Research Ethics Committee of the Universidade Federal de Pernambuco (certificate number: 650.163). All volunteers received clarifications regarding the objectives of the study and those who agreed to participate signed a statement of informed consent.

The sample size was calculated using the formula for the comparison of two proportions with a 1:1 ratio between comparison groups, $80 \%$ power to detect differences, $2.5 \%$ random error rate and $95 \%$ confidence interval. The proportions of each student per age group in each school were calculated based on a total of 1418 , which was the value initially proposed for the basis of the calculation. The sample was selected through a simple randomization process based on the lists of adolescents obtained from the schools. The participants were selected beginning with the first name on the list and alternating (one selected and one not selected), excluding the 12th name selected, which resulted in the initial sample of the study.

The inclusion criteria were age 14 to 19 years, attending class at one of the 11 schools of the public system (municipal and state-run schools) in the city of São Lourenço da Mata in the morning or afternoon shift. Individuals with any systemic disease that could affect their participation and those who stopped attending class were excluded from the study. 
Data collection was performed at the schools between August and December 2015. Non-clinical data were collected first: sociodemographic (sex, age and race), behavioral (oral hygiene frequency, smoking habits, alcohol consumption and leisure activities) and psychosocial (selfesteem and self-perception) factors. Psychosocial factors were collected using a self-administered questionnaire based on the Rosenberg Scale (1965) and Oral Impacts on Daily Performance (OIDP) scale [16]. This questionnaire was administered to groups of students after an explanation of the objectives and methods of the study, with the clarification of all questions that arose during the study.

Next, the clinical data were collected through a periodontal examination using the Community Periodontal Index (CPI) for the determination of the presence/absence of gingival bleeding using the sextant as the unit of analysis (group of six teeth among the 32 teeth in the dental arches). The examinations were performed under indirect natural light and/or artificial light with the adolescent and examiner positioned face to face and the data recorded on a specific clinical chart. The examinations were performed with the aid of a mouth mirror, universal periodontal probe for epidemiological exams (WHO probe), gauze, gloves and mask. The clinical data was collected by three examiners with the assistance of three annotators. The examiners had undergone training and calibration exercises in a pilot study for the detection of gingival bleeding, during which the
Kappa statistic revealed a moderate level of inter-examiner agreement $(K=0.71)$.

For analysis, the data were entered twice into a databank using the Epi Info 6.04 with cross-referencing. The data were submitted to descriptive statistics (frequencies, central tendency and variability measures) and Pearson's chi-square test was used to determine associations between risk factors and gingival bleeding. The statistical analyses were performed with the aid of the Statistical Package for the Social Sciences (SPSS 13.0), with the significance level set at $5 \%(p<0.05)$.

\section{RESULTS}

A total of 1154 adolescents enrolled at public schools in the city of São Lourenço da Mata, state of Pernambuco, northeastern Brazil, participated in the present study. The female sex accounted for $53.5 \%$ of the sample, $34.4 \%$ were 15 years of age and $56.2 \%$ were brown. Gingival bleeding was found in 581 adolescents, corresponding to $50.3 \%$ of the population studied. No significant associations were found between gingival bleeding and the sociodemographic variables evaluated $(p>0.05)$ (table 1).

Considering behavioral factors (table 2), the majority of adolescents (67.3\%) reported not performing

Table 1. Associations between gingival bleeding and sociodemographic data (São Lourenço da Mata, Brazil, 2016).

\begin{tabular}{|c|c|c|c|c|}
\hline \multicolumn{5}{|c|}{ Gingival bleeding } \\
\hline \multicolumn{5}{|l|}{ Sex } \\
\hline Male & $260(48.6)$ & $277(51.6)$ & 0.61 & 0.43 \\
\hline Female & $316(50.7)$ & $304(49.3)$ & & \\
\hline$<15$ & $135(47.4)$ & $150(52.6)$ & 0.79 & 0.37 \\
\hline$>15$ & $458(50.4)$ & $431(49.6)$ & & \\
\hline \multicolumn{5}{|c|}{ Race/skin color } \\
\hline White & $128(49.6)$ & $130(50.4)$ & 0.74 & 0.95 \\
\hline Yellow & $17(44.7)$ & $21(55.3)$ & & \\
\hline Indigenous & $24(46.2)$ & $28(53.8)$ & & \\
\hline
\end{tabular}


any leisure activities and alcohol use was only found in $6.4 \%$. With regard to oral hygiene and smoking, less than $5 \%$ of the participants did not brush their teeth and the same small percentage smoked, whereas the vast majority had positive behavior regarding these two factors.

The psychosocial factors were self-esteem and self-perception. A total of $96.5 \%$ of the sample considered it important to maintain a healthy body and mind and $63.7 \%$ declared being satisfied with their appearance. Regarding the response options on the question addressing self-esteem, 26.6\% marked the low option, 49.3\% marked the moderate option and $24.1 \%$ marked the high option. Considering these psychosocial factors, only satisfaction with one's physical appearance was significantly different in the presence of gingival bleeding $(p<0.05)$ (table 3$)$.

\section{DISCUSSION}

Gingivitis is an inflammatory condition that affects the gingival tissues and is characterized by redness

Table 2. Associations between gingival bleeding and behavioral data (São Lourenço da Mata, Brazil, 2016).

\begin{tabular}{|c|c|c|c|c|}
\hline \multicolumn{5}{|c|}{ Gingival bleeding } \\
\hline & No (\%) & Yes (\%) & $\mathbf{X}^{2}$ & p-value \\
\hline \multicolumn{5}{|c|}{ Leisure activities } \\
\hline Yes & $192(50.9)$ & $185(49.1)$ & 0.36 & 0.54 \\
\hline No & $381(49.0)$ & $396(51.0)$ & & \\
\hline \multicolumn{5}{|c|}{ Alcohol consumption } \\
\hline Yes & $43(58.1)$ & 31 (41.9) & 2.26 & 0.13 \\
\hline No & $529(49.1)$ & 549 (50.9) & & \\
\hline
\end{tabular}

Note: *Pearson's chi-square test.

Table 3. Associations between gingival bleeding and self-esteem/self-perception (São Lourenço da Mata, Brazil, 2016).

\begin{tabular}{|c|c|c|c|c|}
\hline \multicolumn{5}{|c|}{ Gingival bleeding } \\
\hline & No $(\%)$ & Yes (\%) & $\mathbf{X}^{2}$ & p-value \\
\hline \multicolumn{5}{|c|}{ Maintain health (body and mind) } \\
\hline Yes & $550(49.5)$ & $562(50.5)$ & 1.4 & 0.49 \\
\hline No & $14(50.0)$ & $14(50.0)$ & & \\
\hline Does not care & $8(66.7)$ & $4(33.3)$ & & \\
\hline \multicolumn{5}{|c|}{ Physical perception (appearance) } \\
\hline Satisfied & $345(47.0)$ & $389(53.0)$ & 8.25 & 0.01 \\
\hline Unsatisfied & $191(52.8)$ & $171(47.2)$ & & \\
\hline Does not care & $36(64.3)$ & $20(35.7)$ & & \\
\hline \multicolumn{5}{|l|}{ Self-esteem } \\
\hline Low & $153(50.7)$ & $149(49.3)$ & 0.46 & 0.78 \\
\hline Moderate & $278(49.6)$ & $282(50.4)$ & & \\
\hline High & $131(47.8)$ & $143(52.2)$ & & \\
\hline
\end{tabular}

Note: "Pearson's chi-square test. 
and occasional bleeding of the gums. This condition is investigated based on bleeding on probing [16]. Using this indicator, the prevalence of gingivitis was 50.3\% among the adolescents analyzed in the present study. This is similar to the rate reported for northeastern Brazil in the most recent oral health survey (35.2\%) (SB Brasil, 2010) [1] and is also in agreement with previous studies conducted in other states of the country [17-20]. The high occurrence of gingivitis may be explained by the fact that many adolescents do not perform adequate oral hygiene.

The present findings enable outlining a profile of adolescents with bleeding on probing: males aged 15 years or younger, the majority of whom had self-declared brown skin color, did not use alcohol, non-smokers, who did not perform any leisure activities, reported brushing their teeth regularly, were satisfied with their physical appearance, considered it important to maintain one's health and reported having high self-esteem.

Although women have a tendency to exhibit greater concern for their bodies and consequently take more care with regard to oral health [8], this did not appear to exert an influence on plaque control and consequent gingival bleeding in the present study, as $49.6 \%$ of the females had gingivitis. Adolescence is the transition period between childhood and adulthood in which health responsibilities are passed from the parents/guardians to the adolescents themselves, which may explain the greater frequency of gingival bleeding among the participants younger than 15 years of age $[5,12]$.

In the present study, gingival bleeding was not significantly associated with the behavioral factors investigated. Adolescents are seen as a group at high risk for the development of periodontal disease due to a lack of understanding regarding the importance of tooth brushing [5]. Therefore, the fact that the majority of adolescents in the present study reported performing oral hygiene seems to be discordant with the high prevalence of gingival bleeding, the primary factor of which is the buildup of bacterial plaque, with adequate oral hygiene considered the best form of control [2]. In an attempt to clarify this apparent paradox, one may infer that the adolescents do not perform tooth brushing adequately in terms of frequency or technique. It is also possible that the respondents felt a certain degree of pressure to conform to social standards and answered affirmatively to the question due to considering such a response to be socially acceptable, regardless of whether or not oral hygiene was actually practiced. We should therefore reflect on whether it is valid to ask individuals if they brush their teeth, when we should perhaps ask about conditions associated with this behavior, such as the importance individuals give to their mouth and what care they take to ensure oral health.

Analyzing the psychosocial factors of the adolescents with bleeding on probing, little more than half considered it important to maintain the health of one's body and mind and were satisfied with the physical appearance. This raises the question as to why individuals concerned with their health have gingivitis, since this condition can be avoided with basic oral health care, which directly depends on the motivation of adolescents with regard to performing oral hygiene and the main motivation for self-care in this age group is esthetics $[5,6]$. In an attempt to understand this fact, one may infer that gingival bleeding does not affect esthetics, as demonstrated in a study conducted by Carvalho et al. [21], in which $71 \%$ of the 247 adolescents surveyed had not perceived the occurrence of gingival bleeding.

Self-esteem and physical appearance are factors that exert an influence on the motivation for the maintenance of health [22]. The majority of individuals chose the "high" response option when asked about self-esteem, demonstrating a self-judgment of value, confidence and competence [16]. Adequate oral health is an important component of general health, providing effective communication, a varied diet as well as improvements in quality of life, self-esteem and social relations [23].

One of the limitations of the present study regards the use of the CPI, which is limited to the evaluation of one tooth per sextant and therefore information on other teeth is not taken into account, which could lead to an overestimation or underestimation of the data $[23,24]$. Other limitations were absence of a standard setting for the examinations, which were conducted in a room at the schools, some of which had natural light, whereas others had artificial light, and some had more space than others to enable the examiner to find the most adequate position for the examination. Cognitive deficit on the part of the students also led to difficulties understanding some of the questions.

The present study involved a representative sample of 1154 adolescents with a homogeneous population in terms of socioeconomic characteristics. The CPI recommended by the World Health Organization was used, which enables uniformity in the data from different 
locations, facilitating the comparison of data from different countries [4]. The present data can serve as the basis for oral health promotion actions at schools in the city of São Lourenço da Mata, Brazil.

Habits acquired in childhood can last throughout one's entire life [21] and adolescence is a period of the acquisition of behaviors and positive attitudes, making it an ideal time for health promotion [8]. The high percentage of adolescents with gingivitis in the present study (53\%) underscores the need to focus on aspects related to health promotion in order to avoid the aggravation of periodontal disease [23], which is related to a poorer quality of life [25]. This demonstrates the importance of health promotion actions, especially at schools, which play a fundamental role in the acquisition of healthy lifestyles [26].

\section{CONCLUSION}

The prevalence of gingival bleeding among the adolescents analyzed in the present study was high, but did not exert an influence on the satisfaction of these individuals with regard to their physical appearance. The majority reported brushing their teeth, but the high prevalence of gingival bleeding places such declarations under suspicion, leading us to reflect on the best way to investigate this issue.

\section{Collaborators}

BRV PEDROSA, NS DEAMA and LV FILGUEIRAS, participated in the elaboration and development of the research, as well as in data collection and literature review. PSA GOES, performed the analysis of the results, wrote the article and literature review.

\section{REFERENCES}

1. Ministério da Saúde (BR), Secretaria de Atenção à Saúde. SB Brasil 2010: Pesquisa Nacional de Saúde Bucal: resultados principais. Brasília: Ministério da Saúde, 2012 [citado 2017 Maio 17]. Disponível em: <http://bvsms.saude.gov.br/bvs/ publicacoes/pesquisa_nacional_saude_bucal.pdf $>$.

2. Soares D, Andrade C, Pinto AR, Seabra M, Macho V. Doenças da gengiva e periodonto em crianças e adolescentes. Acta Pediatr Port. 2009;40(1):23-29.

3. Carrillo JM, Castillo MG, Hernándes HHR, Zermeño Jl. Estudio epidemiológico de las enfermedades periodontales en pacientes que acuden a la facultad de estomatología de la UASLP. Rev ADM. 2000;57(6):205-213.
4. Araújo MG, Sukekava F. Epidemiologia da doença periodontal na América Latina. Rev Periodontia. 2007;17(2):7-13.

5. Fontes ML, Barbosa MKPO, Sousa SLC, Santiago LM, Firmino RT, Granville-Garcia AF, et al. Avaliação da condição gengival de escolares. Odonto. 2014;22(43-44):13-20.

6. Garbin AS, Garbin AJI, Moimaz SAS, Gonçalves PEA. A saúde na percepção do adolescente. Physis. 2009;19(1):227-238.

7. Souza CHC, Dantas-Neta NB, Laurentino JB, Nunes-Dos-Santos $D L$, Prado Júnior RR, Mendes RF. Fatores de risco relacionados à condição de saúde periodontal em universitários Rev Odontol UNESP. 2013;42(3):152-159.

8. Lima RL, Zamboni GLP, Lima RL, Duarte DA, Sant'Anna GR. Percepções, conhecimentos e representações de saúde bucal em adolescentes de escolas públicas e privadas do município de Atibaia, SP. RFO. 2015;20(2):179-86.

9. Araújo EDS, Costa AJS, Blank N. Aspectos psicossociais de adolescentes de escolas públicas de Florianopólis/SC. Rev Bras Crescimento Desenvolvimento Hum. 2009;19(2): 219-225.

10. Weyne SC. A construção do paradigma de promoção de saúde- Um desafio para as novas gerações. In: Kriger L, coord. ABOPREV: promoção de saúde bucal. $3^{\text {a }}$ ed. São Paulo: Artes Médicas; 2003. p. 1-23.

11. Veiga N, Carvalho P, Coelho I, Ribeiro O. Eficácia da promoção da saúde oral no controlo do biofilme bucal. Rev Bras Promoç Saúde. 2014;27(1):117-23.

12. Bottan ER, De A, Vitoretti J, Santi DG, Garcia E, Silveira D. Percepção de adolescentes sobre as competências essenciais ao cirurgião-dentista. Arq Odontol. 2015;51(3):145-51.

13. Barreto RMA, Cavalcante ASP, Mira QLM, Vasconcelos MIO, Brito M da CC. Ações educativas em saúde para o público adolescente: uma revisão integrativa. Rev APS. 2016;19(2):277-285.

14. Marín C, Papadopol PM, Bottan ER, Orcina BF. Percepção e informação sobre saúde bucal: estudo com adolescentes de uma escola pública. Rev Saúde e Pesquisa. 2017 29;9(3):499. http://dx.doi.org/10.177651/1983-1870.2016v9n3p499-506

15. Santos NCN, Alves TDBA, Freitas VS, Jamelli SR, Sarinho ESC. A saúde bucal de adolescentes: aspectos de higiene, de cárie dentária e doença periodontal nas cidades de Recife, Pernambuco e Feira de Santana, Bahia. Ciênc. Saúde Colet. 2007;12(5):1155-1166.

16. Sbicigo JB, Bandeira DR, Dell'Aglio DD. Escala de Autoestima de Rosenberg (EAR): validade fatorial e consistência interna. Psico-USF. 2010 Set-Dez;15(3): 395-403.

17. Leite LO, Fonseca EP, Ferreira EF, Vargas AMD, Palmier AC, Abreu MHNG. Condição gengival de adolescentes residentes no Vale do Jequitinhonha, Minas Gerais. Arq Odontol. 2013;49(2):75-81.

18. Fernandes L, Costa F, Brandt L, Xavier A, Aguiar Y, Santos $F$, et al. Hábitos de Higiene Bucal e Condição Periodontal de Escolares Adolescentes. Rev Bras Ciências da Saúde. 2016;20(1):37-42.

19. Guitelman I, Mondello A, Cortese SG, Biondi AM, Mondello A, Cortese SG, et al. Autopercepción y salud bucal en 
niños / Self-perception and oral health in children. Rev Circ Argent Odontol. 2013;70(217):24-7.

20. Antunes JLF, Peres MA, Frias AC, Crosato EM, Biazevic MGH. Saúde gengival de adolescentes e a utilização de serviços odontológicos, Estado de São Paulo. Rev Saúde Pública. 2008;42(2):191-9. http://dx.doi.org/10.1590/S0034-891020 08000200002

21. Carvalho RWF, Santos CNA, Oliveira CCC, Gonçalves SRJ, Novais SMA, Pereira MAS. Aspectos psicossociais dos adolescentes de Aracaju (SE) relacionados à percepção de saúde bucal. Ciênc Saúde Coletiva. 2011;16(Supl. 1):1621-1628. http://dx.doi.org/10.1590/S1413-81232011000700098

22. Barbosa TB, Junqueira SR, Frias AC, Araujo ME. Interferência da saúde bucal em funções biológicas e sociais segundo a percepção de adolescentes Brasileiros. Pesqui Bras Odontopediatria Clin Integr. 2013;13(2):171-6.

23. Boeira GF, Salas MMS, Araújo DC, Masotti AS, Correa MB, Demarco FF. Factors influencing dental appearance satisfaction in adolescents: a cross-sectional study conducted in Southern Brazil. Braz J Oral Sci. 2016;15(1):8.

24. Chalub LLF, Péret ACA. Desempenho do índice periodontal comunitário (cpi) na determinação da condição periodontal: enfoque no exame parcial. Arqu Bras Odontol. 2010;6(3):155-62.

25. Lopes MWF, Gusmão ES, Alves RV, Cimões R. Impacto das doenças periodontais na qualidade de vida. RGO, Rev Gaúch Odontol. 2011;59:39-44.

26. Costa GMC, Cavalcanti VM, Barbosa ML, Celino SDM, França ISX, Sousa FS. Promoção de saúde nas escolas na perspectiva de professores do ensino fundamental. Rev Eletr Enf. 2013;15(2):506-15.

Received on: 5/5/2018 Final version resubmitted on: 4/10/2018 Approved on: 5/12/2018 